\title{
Analisis Kebakaran Hutan Dan Lahan Di Provinsi Riau
}

\author{
Ardhi Yusuf ${ }^{1}$, Hapsoh $^{2}$, Sofyan Husein Siregar ${ }^{3}$, Dodik Ridho Nurrochmat ${ }^{4}$ \\ ${ }^{1}$ Direktorat Penegakan Hukum Pidana Kementerian LHK, Gedung Manggala Wanabakti Blok IV Lantai 4 Jl. \\ Gatot Subroto, Senayan, Jakarta \\ ${ }^{2}$ Fakultas Pertanian Universitas Riau Kampus Bina Widya Panam KM 12.5 Pekanbaru, Telp. 0761-862620 \\ ${ }^{3}$ Dosen Pascasarjana Ilmu Lingkungan Program Pascasarjana Universitas Riau, Pekanbaru \\ ${ }^{4}$ Fakultas Kehutanan IPB Kampus IPB Darmaga, Bogor
}

\begin{abstract}
Riau is one of the provinces in Indonesia that often experience forest and land fires. Forest and land fires cause enormous environmental, economic, and social losses and damages that even cause disruption of political relationship between countries. This study aims to determine the relationship between biophysical, socioeconomic, and policy factors in influencing the occurrence of forest and land fires in Riau Province Based on researh, it is known that there is a correlation between forest and land fires variables in Riau Province to distance from 15 variables, ie peatland, river, road, forest cover, plantation cover, plantation, settlement (built up area), dry land, Timber Forest Product Utilization License, plantation concession, other use areas, protected forest areas, production forests, conversion production forest and limited production forest.
\end{abstract}

Key Words: Forest, Land fires, Riau

Kebakaran hutan dan lahan adalah bencana alam yang sering terjadi di Indonesia, terutama pada musim kemarau. Kebakaran ini menyebabkan kerusakan lingkungan yang sangat besar, kerugian ekonomi, dan masalah sosial. Faktanya, kebakaran hutan dan lahan yang besar mengakibatkan dampak asap yang menghancurkan di luar batas administrasi negara (bencana transnasional). Menurut Kementerian Kesehatan (2015) kebakaran hutan dan lahan yang terjadi pada tahun 2015 di beberapa provinsi, seperti Riau, Jambi, dan Sumatera Selatan, menyebabkan bencana terburuk dalam 18 tahun, yang menyebabkan polusi udara parah di beberapa negara Asia Tenggara.

Secara ekologis, penurunan luas hutan dan degradasi lahan akibat kebakaran menimbulkan risiko dan ketidakpastian dalam pemulihan kondisi ekosistem, hilangnya nilai penggunaan kayu dan hutan non-kayu di masa depan dan hilangnya nilai yang diharapkan dari keanekaragaman hayati yang saat ini belum dimanfaatkan (Bahruni et al., 2007).

Beberapa hasil penelitian menunjukkan bahwa kebakaran hutan dan lahan disebabkan oleh berbagai faktor lingkungan seperti iklim, kondisi penutupan lahan, jenis tanah, dan faktor lingkungan bio-fisik lainnya; faktor sosial ekonomi dan faktor kebijakan yang dapat meningkatkan interaksi manusia dengan hutan dan lahan (Tarigan, 2015, Ruchiat, 2001). Menurut Ekadinata dan Dewi (2011) jumlah kegiatan konversi penggunaan lahan yang disebabkan oleh kondisi sosial ekonomi masyarakat dan kebijakan kepemilikan lahan adalah penyebab utama dari tingginya jumlah kebakaran hutan di Indonesia. Oleh karena itu perlu untuk mereformasi kebijakan kehutanan dan pengaturan penggunaan lahan berbasis penggunaan lahan (Barber dan Schweithelm, 2000), terutama dalam ekosistem yang sangat rentan seperti lahan gambut.

Kebakaran hutan dan lahan dapat terjadi baik di dalam maupun di luar kawasan hutan, di tanah mineral dan gambut (Saharjo, 1997; Page et al., 2002; Syaufina 2008). Kebakaran yang terjadi di lahan gambut lebih sulit diatasi karena api dapat menyebar melalui biomassa di atas tanah dan di lapisan gambut di bawah permukaan (Sumantri 2007). Proses membara di lahan gambut ini sulit diketahui penyebarannya secara visual (Rein et al., 2008). Kondisi gambut kering akibat pembukaan lahan dan kanal / parit dapat menyebabkan lahan gambut mudah

terbakar, terutama di musim kemarau yang panjang (Jaenicke et al. 2010). Terkait 
hal ini, Provinsi Riau menjadi salah satu daerah yang perlu mendapat perhatian khusus karena memiliki luas lahan gambut 3,867,413 ha atau $43,61 \%$ dari total luas (Kementerian Pertanian, 2011).

Ketersediaan data / informasi tentang tingkat kerentanan dan potensi kebakaran hutan dan lahan di Provinsi Riau menjadi penting. Sistem Informasi Geografis (SIG) adalah salah satu metode yang dapat memfasilitasi para pemangku kepentingan dalam memantau dan memahami terjadinya kebakaran hutan, apakah insiden tersebut telah terjadi atau prediksi kebakaran di masa depan. Pemodelan spasial kebakaran hutan dan lahan telah menjadi topik studi oleh banyak peneliti, menggunakan berbagai pendekatan dan pertimbangan, termasuk faktor lingkungan (biofisik), sosial ekonomi, dan kebijakan. Jaya et al. (2007) memodelkan kebakaran dengan menggunakan variasi dalam pola iklim lokal (curah hujan), vegetasi (tutupan lahan, kepadatan biomassa, dan kelembaban), penggunaan lahan dan beberapa faktor terkait seperti jarak dari sungai, jalan dan pemukiman. Saito et al. (2002) menilai keterkaitan antara hotspot dan aksesibilitas jalan / sungai sebagai faktor penting dalam pemetaan peta risiko kebakaran di Jambi, Sumatra.

Terjadinya kebakaran hutan dan lahan dipicu oleh berbagai faktor, baik faktor alam maupun faktor manusia. Faktor alami yang sering memicu kebakaran hutan dan lahan adalah kondisi iklim yang ekstrem, seperti musim kemarau yang berkepanjangan karena fenomena El Nino. Berdasarkan penelitian Saharjo dan Husaeni (1998), kebakaran hutan dan lahan di Indonesia diduga lebih disebabkan oleh pengaruh aktivitas manusia daripada faktor alam. Namun, diperlukan analisis kuantitatif yang menjelaskan keterkaitan dan peran masing-masing faktor yang secara signifikan mempengaruhi terjadinya kebakaran hutan dan lahan. Karakteristik lingkungan yang berbeda di setiap wilayah mengarah pada kebutuhan akan penelitian yang dapat menjadi rujukan dalam pengendalian kebakaran yang efektif dan efisien di Provinsi Riau.

Penelitian ini diarahkan untuk mengkaji kebakaran hutan dan lahan dengan pendekatan analisis kuantitatif dan pemodelan spasial aspek biofisik, aspek sosial ekonomi dan aspek kebijakan di Provinsi Riau. Secara khusus, penelitian ini bertujuan untuk: 1). mengetahui keterkaitan antara faktor biofisik, faktor sosial ekonomi dan faktor kebijakan dalam mempengaruhi terjadinya kebakaran hutan dan lahan di Provinsi Riau, 2) mengembangkan model spasial kerentanan hutan dan kebakaran lahan, dan 3) merumuskan kebijakan pengelolaan dan pemanfaatan hutan dan lahan untuk mencegah terjadinya kebakaran hutan dan lahan. Hasil penelitian ini diharapkan dapat memberikan gambaran tentang faktor-faktor yang secara signifikan mempengaruhi terjadinya kebakaran hutan dan lahan di Provinsi Riau, sehingga dapat memberikan masukan bagi Pemerintah Daerah dan pihak terkait dalam menetapkan kebijakan dan peraturan tentang pengelolaan hutan dan lahan dan pemanfaatan.

\section{BAHAN DAN METODE}

Lokasi studi. Penelitian ini dilakukan di semua kabupaten di Provinsi Riau dengan pertimbangan bahwa hampir semua wilayah di Provinsi Riau yang terkena dampak kebakaran hutan dan lahan terjadi setiap tahun (Gambar 1).

Pendekatan penelitian. Metode penelitian ini adalah menganalisis data sekunder yang telah terkumpul dan melakukan metode observasi lapangan untuk mendapatkan data validasi model. Tahapan penelitian terdiri dari 1) pengumpulan data biofisik lingkungan, masyarakat sosial ekonomi dan kebijakan pemerintah, 2) analisis spasial kebakaran hutan dan lahan, 


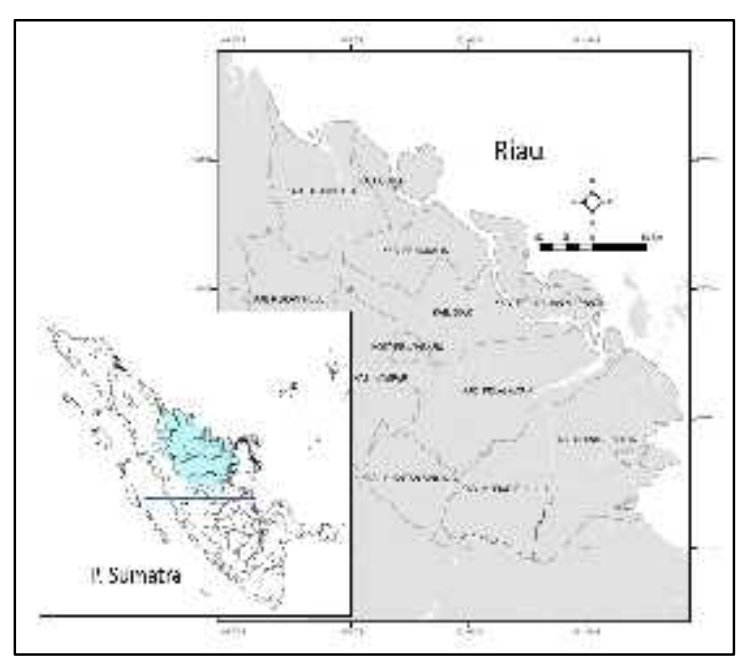

Gambar 1. Lokasi Penelitian

Pengumpulan data. Data yang dibutuhkan dalam penelitian ini adalah: a) Data hotspot yang diperoleh dari ASEAN Specialized Meteorogical Centre (ASMC) diakses melalui http://asmc.asean.org (Portal Informasi Cuaca Singapura) dan Kementerian Lingkungan Hidup dan Kehutanan (KLHK), ) Data curah hujan dari BMKG (Badan Meteorologi, Klimatologi dan Geofisika), c) Peta jenis tanah dari Kementerian Pertanian (Pusat Penelitian dan Pengembangan Pertanian Indonesia), d) Peta tutupan lahan dari Kementerian Lingkungan Hidup dan Kehutanan, e) Bumi Indonesia Peta dengan skala 1: 25000/1: 50.000 (jalan tematik, sungai, dll.), F) Data tabulasi sosialekonomi semua kabupaten di Provinsi Riau dari Statistik Indonesia, g) Peta Rencana Tata Ruang Wilayah Provinsi (RTRW) / D) Tanah status penggunaan, i) Peta Kawasan Hutan, j) konsesi izin usaha pertambangan dan Izin Pemanfaatan Hasil Hutan Kayu, baik hutan alam dan perkebunan (sebelumnya Hak Pengusahaan Hutan dan Hutan Tanaman Industri), k) Data batas wilayah dan 1) Hukum dan penegakan hukum undangundang.

Penentuan unit analisis. Dalam studi ini, karakteristik bio-fisik lingkungan dilakukan pada unit analisis dengan ukuran kotak $250 \mathrm{~m} \quad$ x $250 \mathrm{~m}$, sedangkan karakteristik sosial ekonomi dilakukan di unit analisis desa sebagai unit area pengamatan. Setiap atribut variabel pada unit analisis akan digunakan sebagai input dalam proses analisis statistik.

Pengisian nilai untuk setiap grid dilakukan dengan menghitung jarak (jarak euclidean) ke variabel input. Setiap kisi akan diisi oleh nilai atribut jarak masing-masing variabel, baik variabel dependen maupun independen yang digunakan dalam penelitian ini.Pengisian atribut Grid dilakukan menggunakan modul tambahan perangkat lunak ArcGIS Hawth Tools. Modul ini akan mengisi atribut grid dengan jarak masingmasing variabel pada setiap grid dalam satuan linier. Selanjutnya, pengisian atribut grid untuk variabel sosial ekonomi dan kebijakan dilakukan dengan menggunakan algoritma Zonal Attribute.

Pengumpulan data hotspot sebagai variabel dependen. Analisis data hotspot dilakukan dengan memplot hotspot selama 9 tahun terakhir (2007-2015) untuk menunjukkan posisi hotspot dan distribusi di lokasi penelitian sehingga potensi api dari area penelitian dapat diperoleh (Gambar 2).

Penentuan lokasi pengambilan data hotspot sebagai variabel dependen dilakukan dengan mempertimbangkan penyebaran titik api pada ukuran grid $5 \mathrm{~km}$ x $5 \mathrm{~km}$. Untuk memastikan bahwa lokasi hotspot dapat digunakan sebagai variabel dependen yang representatif, kisi yang memiliki nomor hotspot lebih besar dari 50 poin akan diambil untuk mewakili data hotspot yang akan dimasukkan dalam proses analisis statistik. Setiap kisi terpilih akan diwakili oleh hanya satu data hotspot. Ilustrasi sampel data sampel hotspot ini diilustrasikan dalam Gambar 2

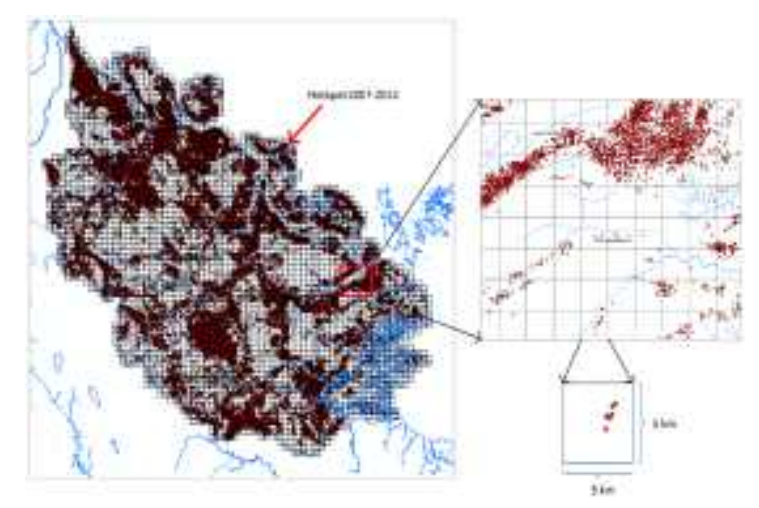

Gambar 2. Penetapan titik sample berdasarkan data titik 
Analisis spasial dan pemodelan spasial dengan metode Regresi Logistik. Regresi adalah analisis statistik yang dapat digunakan untuk memperoleh koefisien hubungan empiris dari pengamatan yang dilakukan. Variabel dependen dari regresi logistik dapat berupa biner atau kategorikal. Variabel independen (regresi logistik) dapat berupa kombinasi variabel kontinu dan kategorikal. Bentuk umum dari regresi logistik dapat dilihat pada persamaan berikut:

$$
P i=\frac{1}{1+\exp \left[-\left(\beta_{0}+\sum_{j=1}^{k} \beta_{j} x_{j i}\right)\right]}
$$

Keterangan:

$P_{i} \quad$ :Probability/peluang

$\beta_{0}, \beta_{1} . . \beta_{k} \quad$ : Koefisien hasil pengukuran

$X_{1}, X_{2} . . X_{k} \quad$ : Variabel/peubah bebas

Persamaan ini menunjukkan probabilitas terjadinya api, yang diwakili oleh variabel respons biner (1 dan 0). Nilai 1 menunjukkan kebakaran, sedangkan nilai 0 menunjukkan tidak ada kebakaran (Xie et al., 2005).

Untuk memodelkan kebakaran dengan regresi logistik, keragaman spasial data harus dipertimbangkan. Statistik spasial seperti ketergantungan spasial dan pengambilan sampel spasial harus dipertimbangkan dalam regresi logistik dengan tujuan menghilangkan korelasi spasial otomatis (Xie et al., 2005). Hasil analisis regresi logistik akan menunjukkan variabel yang paling berpengaruh terhadap terjadinya kebakaran.

Penentuan kriteria untuk model Regresi Logistik. Data hotspot atau area terbakar adalah variabel dependen dalam model regresi logistik. Dalam penelitian ini, hotspot atau kriteria area yang digunakan untuk parameter $\mathrm{Y}$ adalah jumlah hotspot per kisi> 50 untuk kriteria 1 dan $<50$ untuk kriteria 0, di mana setiap kisi hanya akan diwakili oleh satu titik hotspot (1 titik per kisi).

Seperti dijelaskan di atas, untuk menghubungkan interaksi faktor biofisik, faktor sosial ekonomi dan faktor kebijakan dalam model spasial kebakaran hutan dan lahan di Provinsi Riau menggunakan model regresi logistik. Model regresi ini telah digunakan untuk menentukan interaksi faktor lingkungan dan perubahan penggunaan lahan di Jawa (Verburg et al., 2004), model spasial untuk deforestasi (Prasetyo et al., 2009), dan studi tentang perubahan penggunaan lahan pada skala regional (Setiawan, 2013).

Tabel 1. Penentuan kriteria variable yang digunakan dalam model regresi logistik

Variabel yang dipergunakan

Terjadinya kebakaran hutan dan lahan (Variabel tak-bebas / (dependent variable)

Variabel tak-bebas ini merupakan nilai probabilitas terjadinya kebakaran hutan dan lahan $(P i)$
Asumsi dan Kriteria

Terjadinya kebakaran hutan dan lahan didasarkan pada jumlah titik panas (hotspot) tahun 2007 sampai 2015 yang dihitung per grid. Nilai batas diambil pada 50 hotspot per grid dengan asumsi nilai ini mampu mewakili keadaan grid yang memiliki luasan yang cukup besar. Dengan demikian, grid dengan jumlah hotspot $>50$ untuk kriteria 1 dan $<50$ untuk kriteria 0

Variabel bebas (independent variable) yang dipergunakan terdiri atas 17 variabel yang dikelompokan kedalam faktor biofisik, faktor sosial-ekonomi dan faktor kebijakan yaitu:

\section{Faktor Biofisik}

a) Jenis tanah

Input variabel tanah ditentukan dengan

menghitung jarak lokasi ke tanah gambut 
Variabel yang dipergunakan

b) Penutupan lahan
Asumsi dan Kriteria

\section{(DIS_PEAT)}

Input variabel tutupan lahan ditentukan dengan menghitung jarak lokasi pada beberapa tipe tutupan lahan, yaitu:

1. Hutan (DIS_LCFOR)

2. Hutan tanaman industri (DIS_LCFORP)

3. Perkebunan (DIS_LCPLAN)

4. Permukiman (DIS_LCBUIL)

5. Pertanian lahan kering (DIS_LCUPLD)

6. Sawah (DIS_LCPADI)

Jarak terhadap tutupan lahan ini mengindikasikan seberapa besar pengaruh dari tipe tutupan lahan tertentu pada terjadinya kebakaran, baik berkorelasi positif (artinya: semakin jauh semakin meningkatkan probabilitas terjadinya kebakaran), atau negatif (semakin jauh semakin menurunkan probabilitas terjadinya kebakaran).

c) Sungai Input variabel sungai ditentukan dengan menghitung jarak lokasi ke sungai. Sungai dipergunakan sebagai salah satu akses masuk ke lokasi tertentu disinyalir sebagai salah satu faktor yang mempengaruhi terjadinya kebakaran lahan. (DIS_RIV)

d) Jalan Input variabel jalan ditentukan dengan menghitung jarak lokasi ke jalan. Sama hal nya dengan sungai, jarak ke jalan ini merupakan salah satu input data yang terkait dengan aksesibilitas lokasi dan terjadinya kebakaran (DIS_JLN).

\section{Faktor Sosial - Ekonomi}

a) Mata pencaharian di bidang pertanian

Input variabel mata pencaharian diambil dari jumlah keluarga yang memiliki mata pencaharian dari bidang pertanian dalam unit analisis desa. Semakin banyak jumlah keluarga yang bermata pencaharian sebagai petani akan semakin meningkatkan kebutuhan lahan pertanian, sehingga meningkatkan terjadinya kebakaran hutan dan lahan. Agar konsisten dengan input variabel lainnya, variabel mata pencaharian pertanian ini dapat ditentukan dengan menghitung jarak lokasi ke permukiman dan lahan pertanian, seperti pertanian lahan kering (upland) dan sawah (DIS_LCBUIL, DIS_LCUPLD, dan DIS_LCPADI)

b) Status penggunaan lahan
Konsesi perusahaan perkebunan dan kehutanan. Nilai penggunaan lahan ini diambil dengan asumsi bawah areal yang dikuasai oleh perusahaan dan 
Variabel yang dipergunakan

c) Konflik kepemilikan lahan
Asumsi dan Kriteria

dikuasai masyarakat memiliki dampak signifikan pada terjadinya kebakaran. Input variabel diambil dengan menghitung jarak lokasi ke konsesi IUPHHK (DIS_IUPHHK).

Input variabel kepemilikan lahan ditetapkan dengan menghitung jarak lokasi ke batas kepemilikan lahan, baik yang dimiliki perusahaan maupun masyarakat (DIS_KKEBUN).

\section{Faktor Kebijakan Ruang}
a) Pola ruang

\begin{abstract}
Alokasi ruang untuk kehutanan dan non kehutanan merupakan faktor kebijakan yang diambil dengan asumsi semakin luas pola ruang kehutanan maka dapat mengurangi tekanan terhadap pemanfaatan lahan/kawasan hutan. Nilai variabel pola ruang ini didasarkan pada alokasi kawasan hutan berdasarkan SK 878 tahun 2014, yaitu:

1. Hutan lindung (DIS_SKHL)

2. Hutan produksi (DIS_SKHP)

3. Hutan produksi terbatas (DIS_SKHPT)

4. Hutan produksi konversi (DIS_SKHPK)

5. Kawasan Suaka Alam (DIS_SKKSA)

6. Areal penggunaan lain (DIS_SKAPL)
\end{abstract}

Setelah data diolah, langkah berikutnya untuk mendapatkan hubungan aspek lingkungan biofisik, aspek sosial ekonomi dan aspek kebijakan terhadap kejadian kebakaran hutan dan lahan dilihat dari nilai koofisien yang diperoleh dari program SPSS (IBM Corp.)

\section{Uji statistik dan akurasi model.}

Setelah melakukan estimasi parameter, maka pengujian signifikansi parameter ini dilakukan. Untuk tujuan ini, pengujian hipotesis statistik digunakan untuk menentukan apakah variabel independen dalam model signifikan atau secara signifikan mempengaruhi variabel dependen. Pengujian signifikansi parameter dilakukan sebagai berikut:

Uji multikolinieritas._Prasyarat yang harus dipenuhi dalam model regresi adalah tidak adanya multikolinieritas. Dengan demikian, uji multikolinieritas diperlukan. Uji multikolinieritas digunakan untuk mengetahui apakah dalam model regresi ditemukan korelasi antara variabel independen. Ada beberapa metode pengujian yang dapat digunakan seperti: dengan melihat nilai Toleransi dan Varians Inflation Factor (VIF) dalam model regresi, dengan membandingkan koefisien determinasi individu (r2) dengan nilai determinasi simultan (R2). , dan dengan melihat nilai nilai eigen dan indeks kondisi. Dalam penelitian ini, uji multikolinieritas yang digunakan adalah untuk melihat nilai Toleransi dan VIF. Dasar pengambilan keputusan berdasarkan nilai Toleransi dan VIF adalah: jika nilai Toleransi masing-masing variabel independen> 0,1 maka tidak ada multikolinearitas dan jika nilai Toleransi <0,1 maka terjadi multikolinieritas. Selanjutnya, jika nilai VIF masing-masing variabel bebas <10 maka multikolinieritas tidak terjadi dan jika nilai> 10 maka multikolinieritas terjadi. Jika dalam keseluruhan hasil tes terdapat variabel independen dengan nilai Toleransi $<0,1$ dan VIF> 10, maka kita harus menghilangkan variabel tersebut. Hanya variabel independen yang signifikan dan tidak ada multikolinieritas 
yang akan diproses dalam analisis regresi logistik.

Uji kelayakan. Model Uji kelayakan model berguna untuk menilai kemampuan model untuk memprediksi variabel dependen. Penilaian kelayakan model berkaitan dengan pencarian kedekatan nilai prediksi model dengan nilai yang diamati. Model uji kelayakan menggunakan uji Hosmer-Lemeshow. Tes Hosmer-Lameshow cocok untuk model yang terdiri dari beberapa variabel independen yang diskrit atau kontinu (Hosmer et al. 1997). Variabel independen dianggap sesuai dengan model jika signifikansi hasil tes HosmerLemeshow di atas 0,05 . Koefisien determinasi (R2) ditentukan dengan melihat hasil uji Negelkerke R2 dan persentase yang benar (persentase keseluruhan). Negelkerke R2 menunjukkan pentingnya variabel independen dalam memprediksi variabel dependen. Semakin besar nilai yang dihasilkan Negelkerke R2 semakin baik modelnya. Persentase yang benar digunakan untuk melihat kemampuan model dalam memprediksi kondisi aktual. Semakin besar Persentase prediksi yang benar, semakin baik kondisi aktualnya.

Validasi Model. Validasi model dilakukan untuk menentukan apakah model telah dibuat sesuai dengan kondisi aktual. Data titik validasi yang digunakan terutama diambil dari area yang benar-benar berubah di dunia nyata dan area yang telah berubah berdasarkan peta perubahan yang telah dibuat. Persamaan yang terkait dengan persentase validitas model adalah sebagai berikut:

Validasi $=\mathrm{n} / \mathrm{N} \times 100 \%$

Di mana $\mathrm{n}=$ jumlah titik kejadian kebakaran hutan dan lahan ditemukan pada kelas kesesuaian, dan $\mathrm{N}=$ jumlah total poin untuk kejadian kebakaran hutan dan lahan ditemukan di semua kelas kesesuaian. Pada tahap validasi model, ada dua kesalahan: kesalahan kelalaian dan kesalahan komisi. Diterjemahkan dari Boone dan Krohn (1999) dan Ottaviani et al (2004), Kesalahan kelalaian adalah model yang memprediksi lokasi tidak sesuai untuk terjadinya perubahan, tetapi pada lokasi sebenarnya dari perubahan tersebut. Komisi kesalahan adalah model yang memprediksi lokasi yang sesuai untuk terjadinya perubahan, tetapi pada lokasi yang sebenarnya tidak ada perubahan ..

\section{HASIL}

Faktor pendorong yang mempengaruhi terjadinya kebakaran hutan dan lahan di Provinsi Riau dikelompokkan menjadi: 1) faktor biofisik lingkungan, 2) faktor sosial ekonomi dan 3) faktor kebijakan tata ruang. Pengelompokkan faktor-faktor pendorong tersebut telah diungkapkan dalam beberapa hasil penelitian sebelumnya di daerah tropis (Barber dan Schweithelm, 2000; Geist dan Lambin, 2002; Chowdhury, 2006; Miettinen dan Liew, 2005).

\section{Faktor Biofisik Lingkungan}

Secara umum, karakteristik biofisik lingkungan yang mempengaruhi kebakaran hutan dan lahan adalah tutupan lahan, curah hujan, ketinggian, kemiringan lahan, jaringan sungai dan aksesibilitas jalan (Geist dan Lambin, 2002).

Di beberapa spesifik lokasi di Sumatera dan Kalimantan, terjadinya kebakaran sangat dipengaruhi oleh kondisi tutupan lahan dan jenis tanah, yang sangat berkaitan dengan ketersediaan biomassa yang menjadi salah satu komponen utama terjadinya kebakaran. Pada kondisi tertentu seperti musim kemarau yang ekstrim, ketersediaan biomassa yang tinggi akan memperbesar potensi terjadinya kebakaran lahan (Saharjo et al. 1998).

Lahan gambut merupakan salah satu ekosistem esensial yang memiliki tingkat kerawanan kebakaran yang cukup tinggi (Appanah 1997). Hal ini disebabkan lahan gambut mengandung material atau bahan organik sangat banyak yang tertimbun secara alami dalam keadaan basah, bersifat tidak mampat dan hanya sedikit mengalami perombakan. Secara alami, kondisi lahan gambut yang selalu basah ini sulit terbakar (Effendy 1998). Meskipun demikian, pengeringan lahan gambut sering kali disebabkan oleh kegiatan pembukaan lahan, melalui pembangunan kanal-kanal tanpa memperhatikan permukaan air tanah.

Luas lahan gambut di Propinsi Riau diperkirakan sekitar 4.827.972 Ha atau 51,06\% 
luas wilayah daratan Provinsi Riau. Lahan gambut tersebut dijumpai di seluruh wilayah kabupaten/kota di Provinsi Riau. Distribusi lahan gambut paling luas terdapat di Kab. Bengkalis dan Kab. Indragiri Hilir. Distribusi lahan gambut di Provinsi Riau (BBSDLPKementan, 2002) disajikan pada Gambar 5. Pembukaan hutan yang terjadi saat ini menyebabkan lahan gambut menjadi lebih terbuka, dan menjadikan lahan gambut sangat rentan terbakar khususnya pada musim kemarau yang ektrim.

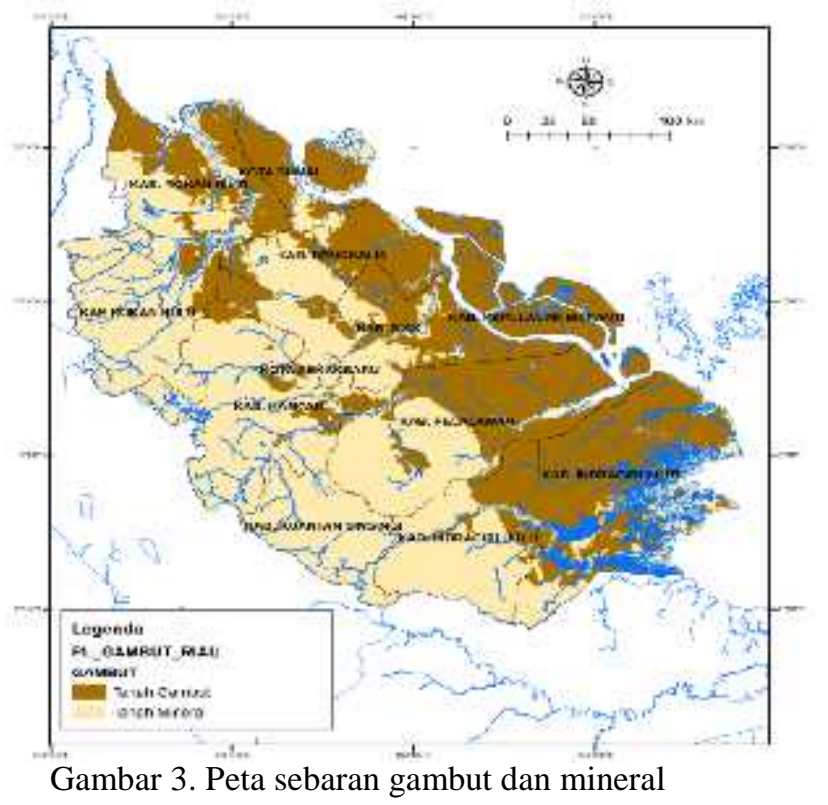

Berdasarkan hasil analisis perubahan tutupan lahan yang dikeluarkan oleh Ditjen Planologi Kehutanan dan Tata Lingkungan, KLHK (2016) menunjukkan bawah dinamika perubahan luas tutupan hutan di wilayah Provinsi Riau berkaitan dengan peningkatan luas areal perkebunan dan hutan tanaman. Hasil analisis tersebut menunjukkan bahwa penurunan luas hutan tahun 2006 sampai 2015 mencapai $41,22 \%$. Di sisi lain, terjadi peningkatan luas perkebunan sebesar $41,4 \%$ dan hutan tanaman sebesar $27,80 \%$.

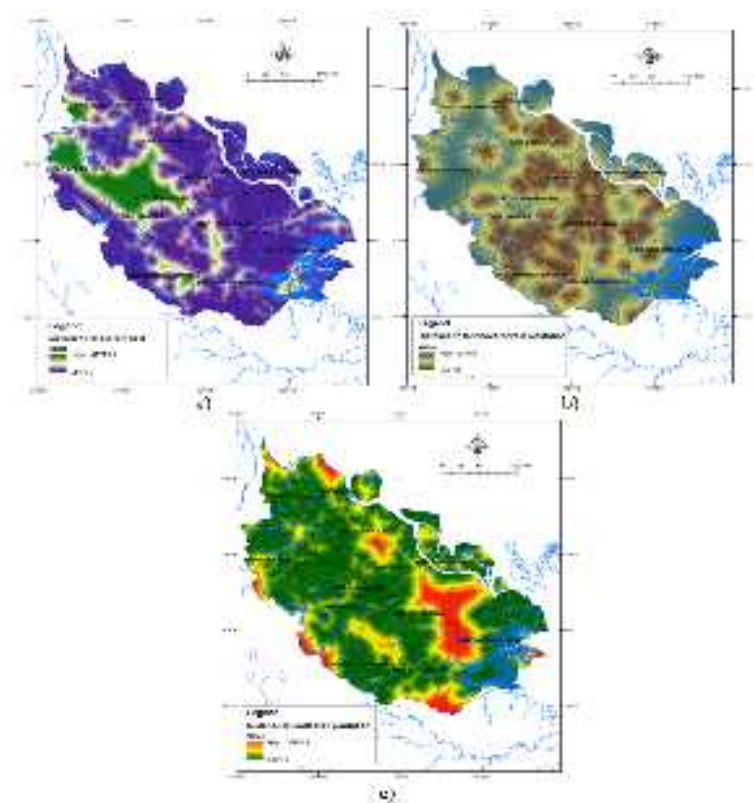

Gambar 4 Peta jarak terhadap a) tutupan hutan, b) tutupan hutan tanaman dan c) tutupan perkebunan

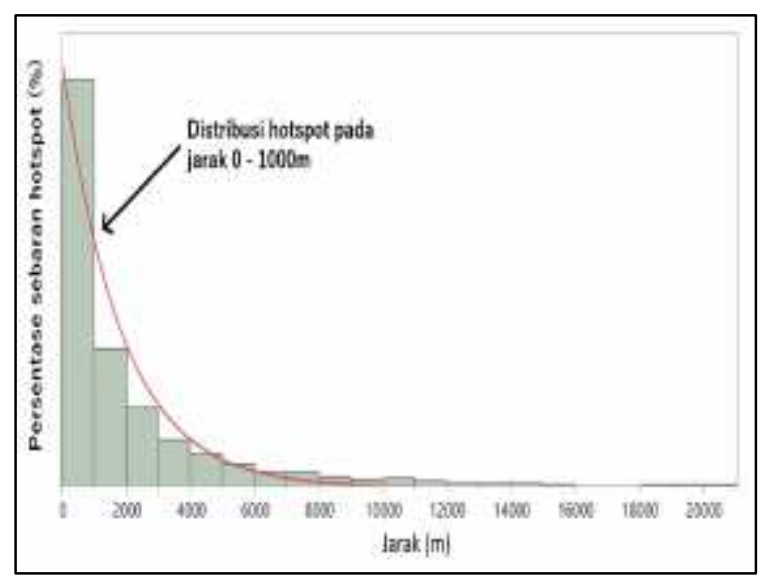

Gambar 5 Tren distribusi titik panas berdasarkan jarak terhadap jalan

\section{Faktor Sosial Ekonomi}

Berdasarkan kajian yang dilakukan oleh Barber dan Schweithhelm (2000) masalah kebakaran lahan dan hutan di Sumatra sangat erat kaitannya dengan faktor sosial ekonomi dan perilaku yang disengaja, baik oleh masyarakat maupun perusahaan. Walaupun faktor alam dapat menjadi pendorong terjadinya kebakaran hutan dan lahan, namun sebagian besar pemicu kebakaran hutan dan lahan diyakini bersumber dari aktivitas manusia. Dalam rangka efisiensi biaya, masyarakat dan para pelaku bisnis sering melakukan aktivitas pembersihan lahan (land clearing) dengan cara sangat tidak ramah lingkungan, yakni berupa aktivitas pembakaran yang akhirnya berujung pada kebakaran lahan dan hutan di sekitar areal perkebunan. 

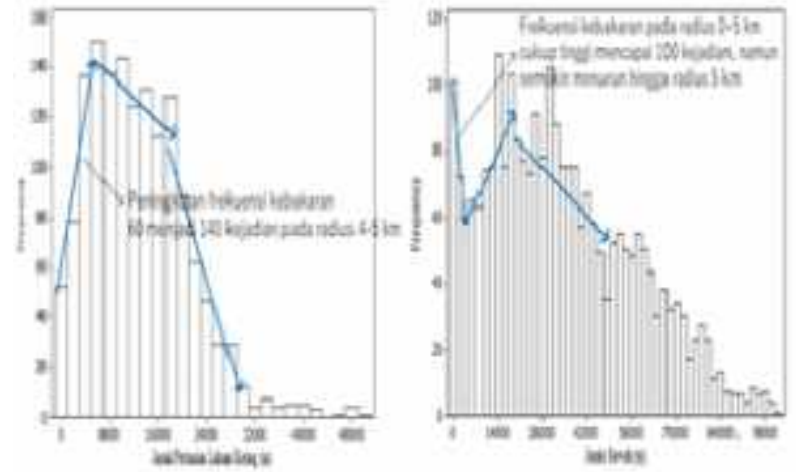

Gambar 6.Distribusi titik panas berdasarkan jarak terhadap lahan pertanian lahan kering (kiri) dan sawah (kanan)
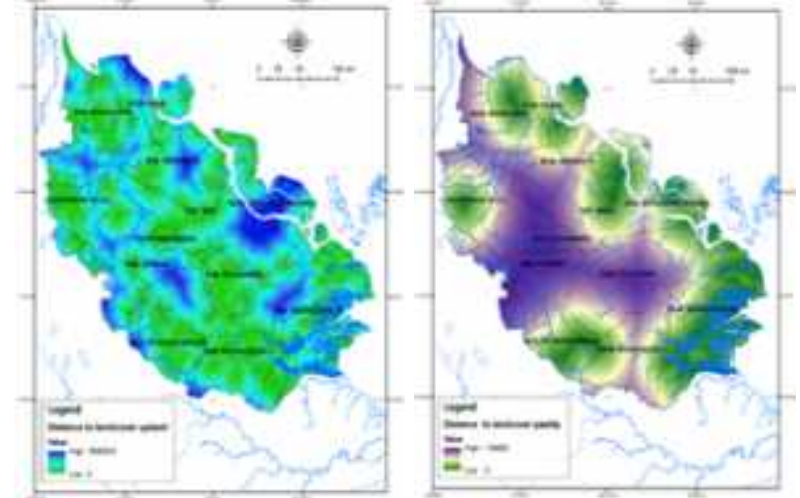

Gambar 7. Peta jarak ke tutupan pertanian lahan kering (a) dan tutupan sawah $(b$

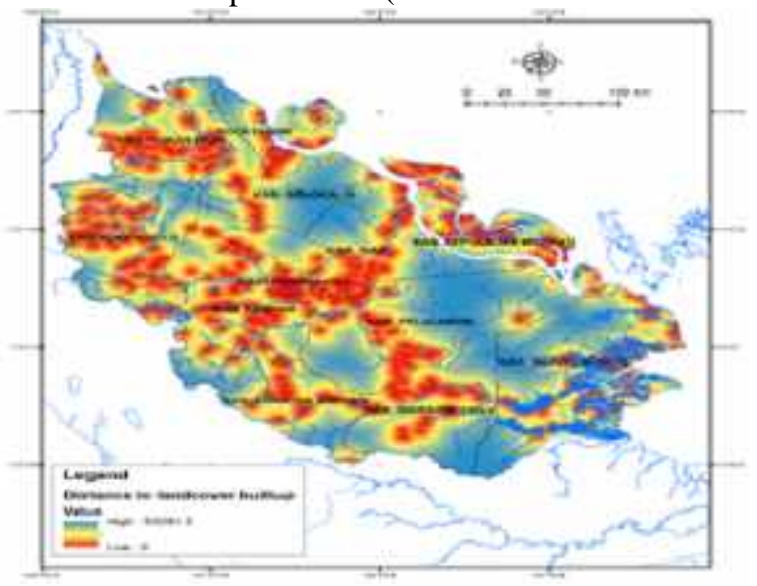

Gambar 8 Peta jarak tutupan lahan terbangun

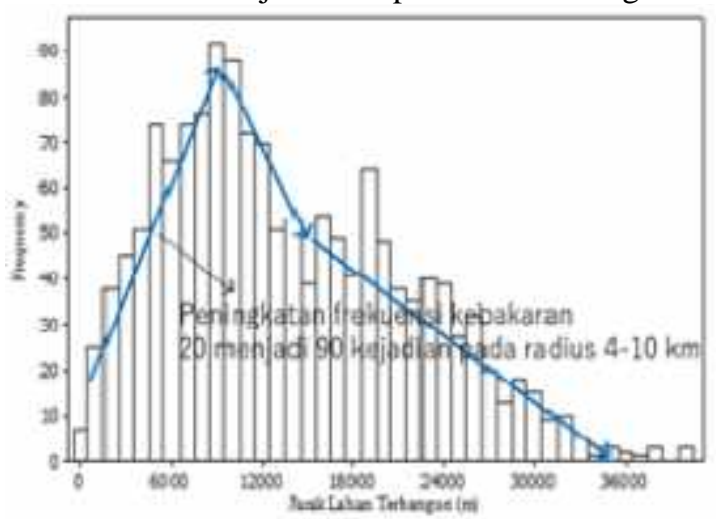

Gambar 9 Jarak pemukiman terhadap titik panas

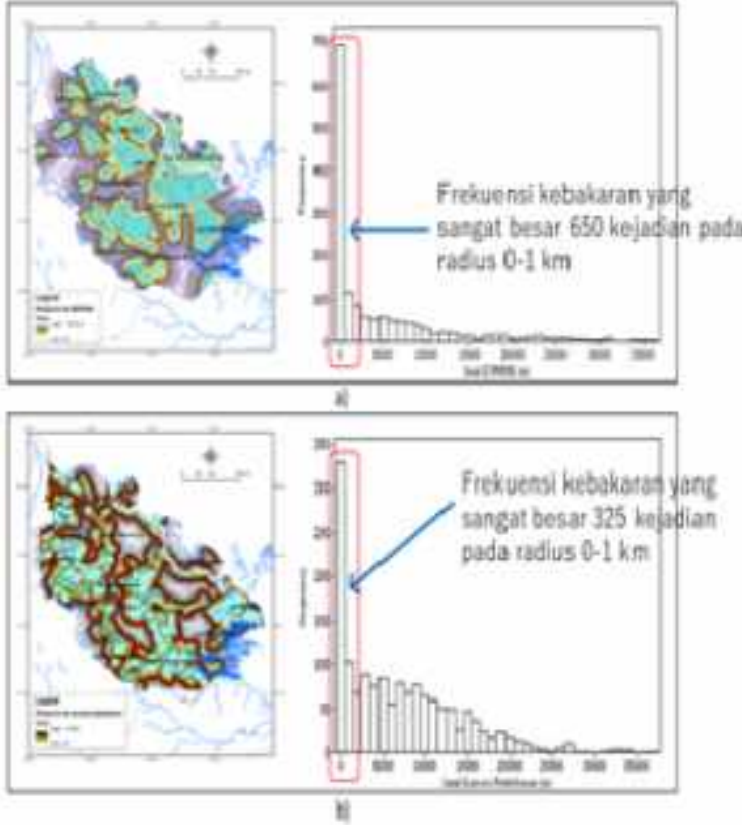

Gambar 10 Jarak sebaran titik panas terhadap jarak lokasi ijin a) IUPHHK, b) HGU

\section{Faktor Kebijakan dan Alokasi Ruang}

Beberapa faktor kebijakan yang mempengaruhi tingginya tingkat kebakaran hutan dan lahan di Provinsi Riau antara lain:

a. Provinsi Riau belum memiliki Rencana Tata Ruang Wilayah (RTRW) yang definitif (baru disahkan pada tahun 2018)

b. Tidak tegasnya pemerintah dalam menangani kawasan sebagai berikut :

1. Kawasan ex HPH yang sampai saat ini tidak jelas statusnya

2. Kawasan sempadan sungai

3. IUPHHK-HT/HA yang telah keluar izinnya tetapi tidak diusahakan

Gambar 11 menunjukkan bahwa semakin dekat jarak ke lokasi kawasan hutan baik hutan produksi (HP), hutan produksi terbatas (HPT), maupun hutan produksi konversi (HPK), maka semakin besar resiko terjadinya kebakaran 

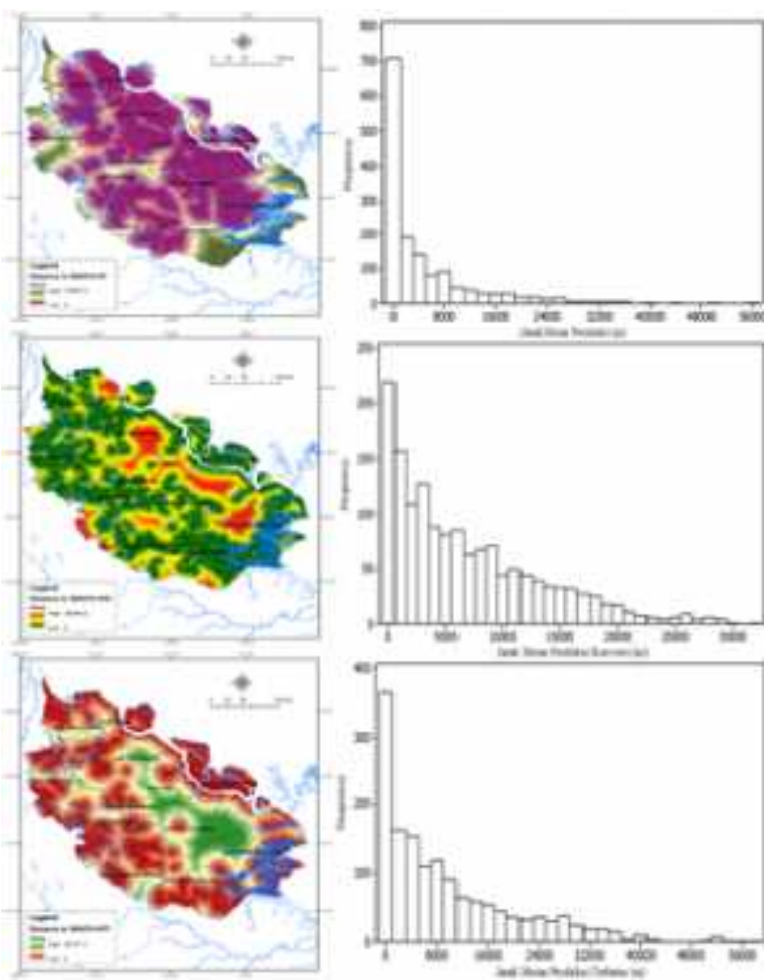

Gambar 11 Sebaran titik panas berdasarkan jarak terhadap lokasi kawasan hutan sesuai SK 878: a) Hutan Produksi/HP, b) Hutan Produksi Konversi/HPK dan c) Hutan Produksi Terbatas/HPT.
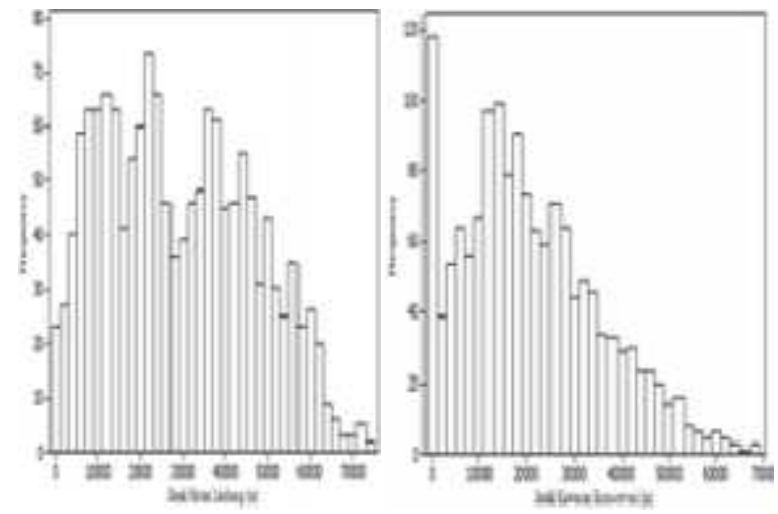

Gambar 12 Sebaran titik panas berdasarkan jarak terhadap lokasi kawasan hutan sesuai SK 878: a) Hutan Lindung/HL, b) Kawasan Konservasi.
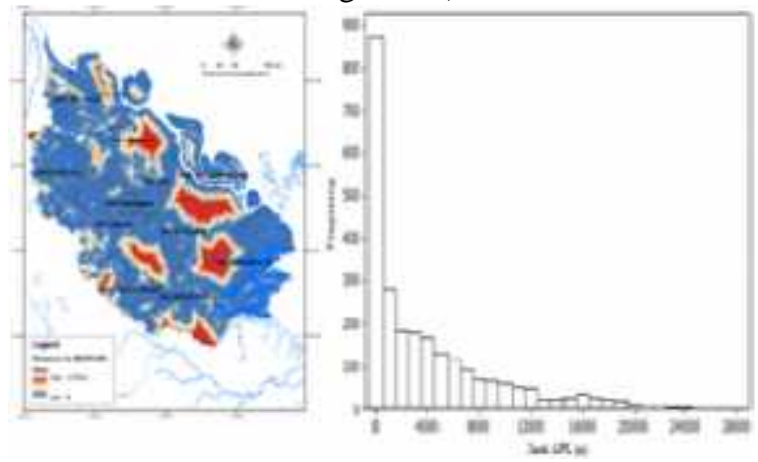

Gambar 13 Sebaran titik panas berdasarkan jarak terhadap lokasi areal penggunaan lain (APL) sesuai SK 878

\section{PEMBAHASAN}

\section{Faktor Biofisik Lingkungan}

Berdasarkan distribusi data titik panas tahun 2007 sampai 2015, dapat dilihat bahwa lebih dari $80 \%$ titik panas berada di lahan gambut (Gambar 6). Secara akumulasi data titik panas terdapat di tanah gambut sebanyak 9371 titik (83.1\%), sedangkan tanah mineral sebanyak 1905 titik (16.9\%). Berdasarkan analisis data titik panas multiwaktu tahun 2007 hingga 2015, lebih dari $77.3 \%$ kebakaran hutan dan lahan yang terjadi di Provinsi Riau terjadi di lahan gambut. Hal ini terjadi disebabkan lahan gambut yang berada pada kondisi kering sangat mudah untuk terbakar dibandingkan dengan lahan tanah mineral (Page dan Hooijer, 2016).

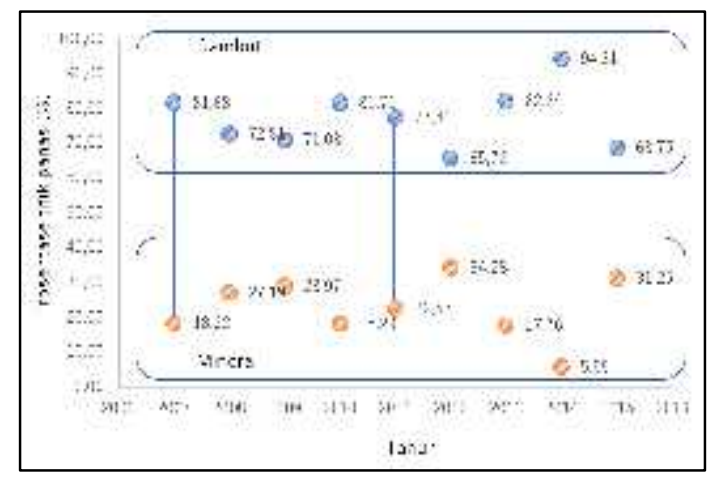

Gambar 14 Perbandingan kejadian kebakaran hutan/lahan berdasarkan sebaran jumlah titik panas di tanah gambut dan mineral

Berdasarkan hasil analisis jarak lokasi titik panas dan lahan gambut menunjukkan kecenderungan bahwa jumlah titik panas semakin tinggi di areal lahan gambut hingga jarak atau radius $2.500 \mathrm{~m}$ dari lokasi gambut (Gambar 15). Kondisi ini menunjukkan bahwa lahan gambut sangat rentan terbakar, terutama ketika lahan gambut berada pada kondisi kering.

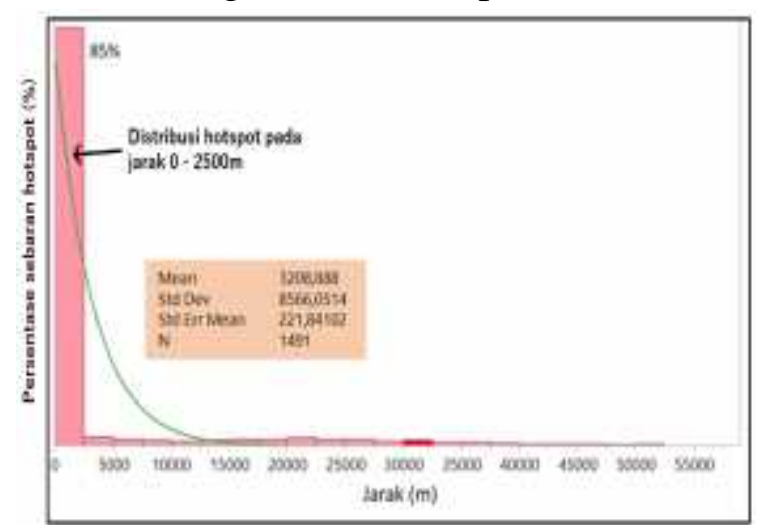

Gambar 15 Sebaran titik hotspot berdasarkan jaraknya (radius) terhadap tanah gambut 
Data sebaran lokasi titik panas ini sangat penting sebagai petunjuk awal kemungkinan terjadinya titik panas, tetapi juga sebagai referensi untuk melakukan prediksi bahwa kebakaran telah terjadi di berbagai lokasi dan bersifat dinamik. Selain dipengaruhi karakteristik lahan gambut yang mudah terbakar, sebaran titik panas diduga mengikuti pola tertentu yang sangat berhubungan dengan kondisi tutupan lahan (Setiawan et al, 2017).

Pengembangan hutan tanaman industri, perkebunan sawit dan budidaya pertanian lainnya di lahan gambut dengan menggunakan sistem kanal untuk mengatur tinggi muka air sangat rentan menyebabkan kebakaran, terutama bila pembangunan kanal di lahan gambut ini tidak dilakukan secara terpadu dalam satu hamparan lahan. Hal ini disebabkan kanal yang dibangun pada lahan gambut tersebut akan diikuti dengan aliran air keluar dari areal gambut menuju kanal yang mengakibatkan lahan gambut menjadi kering dan menjadi sangat mudah terbakar.

Hasil penelitian Konecny et al (2015) menunjukkan bahwa lahan gambut yang berdekatan dengan kanal drainase hingga $600 \mathrm{~m}$ sangat rentan terbakar dibandingkan dengan lahan gambut yang jauh dari kanal $(>1.300 \mathrm{~m})$, dimana lahan gambut yang berlokasi dekat dengan kanal dapat terbakar hingga 3-4 kali lebih sering dibandingkan dengan lahan gambut yang cukup jauh dari kanal. Di lahan gambut tropis, seperti di Provinsi Riau, terjadinya kebakaran hutan dan lahan sangat dipengaruhi oleh karaktersitik lahan gambut dan jaraknya terhadap kanal drainase (Page dan Hooijer, 2016).

Berdasarkan hasil analisis perubahan tutupan lahan yang dikeluarkan oleh Ditjen Planologi Kehutanan dan Tata Lingkungan, KLHK (2016) menunjukkan bawah dinamika perubahan luas tutupan hutan di wilayah Provinsi Riau berkaitan dengan peningkatan luas areal perkebunan dan hutan tanaman. Hasil analisis tersebut menunjukkan bahwa penurunan luas hutan tahun 2006 sampai 2015 mencapai $41,22 \%$. Di sisi lain, terjadi peningkatan luas perkebunan sebesar $41,4 \%$ dan hutan tanaman sebesar $27,80 \%$.

Berdasarkan data Dinas Kehutanan Prov. Riau (2012) luas deforestasi mencapai 139.550 ha/tahun yang dihitung berdasarkan rata-rata penurunan luas hutan sejak tahun 1985 sampai 2012. Penurunan luas hutan di wilayah Riau ini didominasi oleh penurunan tutupan hutan di hutan rawa $(61,30 \%)$, baik hutan rawa primer maupun hutan rawa sekunder. Hutan rawa tipe ini rentan terhadap kebakaran yang disebabkan oleh tingginya kandungan biomassa yang dapat menjadi sumber bahan bakar.

Hutan sekunder juga rawan kebakaran, karena telah menjadi daerah terbuka. Sebagian besar usaha hutan tanaman industri, perkebunan kelapa sawit dan budidaya pertanian lainnya di lahan gambut mempergunakan sistem kanalisasi untuk mengatur tinggi muka air. Kanalisasi lahan gambut tidak dilakukan secara menyeluruh dan terpadu dalam satu hamparan lahan. Akibatnya, saat kanalisasi diberlakukan maka terjadi aliran air dari areal gambut yang posisinya lebih tinggi dan mengakibatkan hilangnya debit air sehingga menyebabkan kekeringan pada beberapa bagian lahan gambut. Lahan gambut yang kering ini menjadi sumber bahan bakar yang mudah terbakar dan menyebabkan terjadinya kebakaran hutan dan lahan.

Di samping keberadaan kanal (sungai) di lahan gambut dapat menyebabkan kondisi gambut menjadi kering, sehingga sangat mudah terbakar (Page dan Hooijer, 2016), namun faktor fisik lain yang mempengaruhi kebakaran hutan dan lahan adalah jaringan jalan. Penelitian Hadi (2006) menyatakan bahwa kebakaran lahan di Provinsi Riau sangat mudah terjadi pada areal yang dapat diakses oleh masyarakat, sehingga adanya jaringan jalan dapat meningkatkan akses terhadap lahan yang akan dibuka. Ketersediaan akses jalan (aksesibilitas) yang dapat dipergunakan oleh masyarakat, meningkatkan peluang terjadinya kebakaran.

Hal ini menunjukkan bahwa jarak yang semakin dekat dengan jaringan jalan akan meningkatkan peluang terjadinya kebakaran. Gambar 10 menunjukkan tren distribusi titik panas berdasarkan jarak terhadap jalan.

Selain faktor biofisik lingkungan, kondisi iklim juga merupakan faktor alam yang menjadi pemicu kebakaran hutan dan lahan, seperti musim kemarau berkepanjangan (ekstrem). Salah satu kebakaran hutan dan lahan terbesar terjadi pada tahun 1997 sampai 1998, pada saat itu berbagai tempat di dunia termasuk Indonesia 
mengalami musim ekstrim yang dipercaya menjadi faktor penyebab kebakaran hebat yang menghanguskan hutan seluas 25 juta ha di seluruh dunia. Bencana kebakaran hutan dan lahan akibat musim kering yang panjang juga terulang pada tahun 2002 (Tacconi 2003).

\section{Faktor Sosial Ekonomi}

Gambar 6 menunjukan bahwa kedekatan lokasi lahan pertanian terhadap lahan yang terbakar, lebih dipengaruhi oleh kedekatan terhadap lahan sawah dibandingkan dengan pertanian lahan kering pada radius $0-1 \mathrm{~km}$ dari lokasi kebakaran. Namun frekuensi terjadinya kebakaran semakin menurun dengan semakin jauhnya lahan hingga jarak $5 \mathrm{~km}$ dari lahan sawah, sebaliknya dengan pertanian lahan kering. Lokasi terbakar mencapai frekuensi kejadian yang cukup tinggi di lahan pertanian yang berada pada radius $4-5 \mathrm{~km}$. Hal ini dimungkinkan terjadi di lahan gambut, dimana kejadian kebakaran memiliki interval jarak yang cukup jauh dengan sumber api nya, karena api merambat di bawah permukaan tanah (Page dan Hooijer, 2016).

Gambar 7 menunjukkan bahwa semakin dekat jarak dari pertanian lahan kering dan sawah maka semakin besar resiko terjadinya kebakaran mengingat kegiatan pembukaan lahan seringkali menggunakan api. Meskipun demikian, pengaruh aktivitas pertanian terhadap terjadinya kebakaran lahan pada pertanian lahan kering jauh lebih tinggi dibandingkan dengan sawah

Hasil analisis diatas menunjukan bahwa hingga jarak radius $8 \mathrm{~km}$ dari lahan pertanian lahan kering resiko terjadinya kebakaran cukup besar. Hal ini disebabkan oleh kegiatan pembukaan lahan yang dilakukan masyarakat seringkali menggunakan api. Praktik pembukaan lahan dengan cara dibakar ini terus terjadi karena keterbatasan modal masyarakat.

Kebakaran hutan dan lahan di Provinsi Riau terjadi hampir setiap tahun, terutama di musim kemarau. Salah satu penyebabnya adalah aktivitas masyarakat dalam mengolah lahan pertanian/perkebunan dengan menggunakan metode tebas-bakar (slash and burn). Perilaku tersebut didasarkan pada beberapa pertimbangan, antara lain: keterbatasan tenaga kerja, keterbatasan mobilitas menuju lahan serta keterbatasan modal, sehingga pembakaran adalah salah satu cara penyiapan lahan yang paling mudah dan murah. Terkait hal ini, penyiapan lahan tanpa bakar (zero burning) adalah solusi yang harus ditetapkan dan dilaksanakan, namun pada umumnya diperlukan bantuan alat-alat mekanis yang tidak murah pengadaannya. Sehingga peran serta pemerintah, baik pusat maupun daerah, dan pelaku usaha harus memiliki perencanaan yang baik agar dapat membiayai penyiapan lahan tanpa bakar secara efisien dan efektif.

Faktor ekonomi dan penguasaan lahan mendorong terjadinya perilaku membakar hutan, khususnya untuk memperoleh lahan pertanian (lahan kering). Dengan demikian, kebakaran hutan dan lahan tidak terlepas dari permasalahan agraria. Perkembangan ekonomi ini terkait erat untuk pemenuhan kebutuhan masyarakat yang dilakukan dengan pembukaan lahan untuk usaha pertanian. Oleh karena itu, untuk memasukkan input variabel sosial ekonomi dalam pemodelan spasial, maka digunakan data sosial ekonomi berupa data jumlah keluarga yang memiliki mata pencaharian di bidang pertanian dalam unit administrasi desa. Asumsi yang dipergunakan adalah semakin banyaknya jumlah keluarga yang bermata pencaharian sebagai petani akan semakin meningkat juga kebutuhan terhadap lahan pertanian, sehingga meningkatkan terjadinya kebakaran hutan dan lahan.

Fakta yang diperoleh dari lapangan, dalam berita sejumlah media dan hasil penelitian (Rusdiyanto 2000) menunjukkan bahwa faktor manusia sebagai penyebab utama bencana asap, melalui pembakaran lahan yang dilakukan baik secara sporadis maupun sistematis. Tidak adanya rasa memiliki (sense of belonging) dan kurangnya rasa tanggungjawab (sense of responsibility) dalam menjaga kelesatarian ekologi, merupakan bentuk perubahan budaya yang tidak toleran terhadap alam.

Pertumbuhan penduduk yang menekan peningkatan kebutuhan akan lahan mengakibatkan terjadinya perubahan nilai budaya. Membakar lahan dalam persiapan penanaman komoditas perkebunan dilakukan atas bias pertimbangan ekonomis dan efisiensi karena lahan yang dibutuhkan semakin luas. Demikian juga hal tuntutan skala usaha komoditas komersial kelapa sawit. Pada kondisi ini, pertimbangan budaya hidup serasi dengan 
alam sudah mulai ditinggalkan. Secara sadar ataupun tidak, masyarakat pada umumnya telah memilih tindakan eksploitasi lahan sebagai upaya mengejar peningkatan taraf hidup dari kondisi kemiskinan yang selama ini dialami. Petani mulai menerapkan sistem nilai budaya industri yang menekankan kepentingan individual-personal, komersial, dan eksploitatif terhadap sumberdaya (Soetrisno 1995).

Gambar 8 dan 9 menunjukkan jarak keberadaan pemukiman dalam mempengaruhi terjadinya kebakaran hutan dan lahan. Hasil analisis menunjukkan bahwa sebaran titik panas cukup tinggi berada pada jarak 4 hingga $10 \mathrm{~km}$ dari permukiman (lahan terbangun). Pengaruh keberadaan pemukiman terhadap potensi terjadinya kebakaran lahan telah dikaji dalam studi Jafarzadeh et al (2017), dimana evaluasi resiko kebakaran hutan dilakukan dengan menggunakan algoritma Apriori dan fuzzy cmeans clustering. Hasil kajian ini menunjukkan bahwa kasus kebakaran hutan di Indonesia secara signifikan dipengaruhi oleh 8 variable, dimana diantaranya adalah jarak dari pemukiman. Potensi kebakaran hutan di Iran semakin tinggi dengan semakin dekatnya lokasi tersebut dari permukiman

Beberapa kasus kejadian kebakaran di Provinsi Riau terjadi di areal perusahaan atau sekelompok orang yang mengatasnamakan kelompok masyarakat yang memiliki Hak Guna Usaha (HGU) dan daerah kawasan konservasi tertentu yang dikuasai atau dikelola oleh perusahaan, sehingga diperlukan adanya analisis berupa status penggunaan lahan dan konflik penguasaan lahan.

Gambar 10 diatas menunjukkan pengaruh kepemilikan areal oleh perusahaan terhadap sebaran titik panas, penggunaan data lokasi ijin pemanfaatan lahan baik IUPHHKK maupun HGU. Hasil analisis tersebut menunjukkan bahwa sebagian besar titik panas berada di dalam wilayah konsesi perusahaan a) IUPHHKK dan b) HGU. Sebanyak 642 titik panas yang diduga titik kejadian kebakaran $(43.06 \%)$ berada tepat di kawasan IUPHHK, 760 titik panas $(50.97 \%)$ berada pada jarak kurang dari $1000 \mathrm{~m}$ dari kawasan IUPHHK. Sedangkan untuk konsesi perkebunan (HGU), sebanyak 297 titik panas yang diduga titik kejadian kebakaran (19.92\%) berada tepat di kawasan konsesi perkebunan, 384 titik panas
$(25.75 \%)$ berada pada jarak kurang dari $1000 \mathrm{~m}$ dari kawasan perkebunan.

Faktor kesengajaan dalam kebakaran hutan dan lahan pada umumnya terkait dengan konflik penguasaan lahan. Dalam menyikapi klaim lahan dan konflik berkepanjangan yang dilakukan masyarakat terhadap perusahaan, baik karena alasan "genuine" maupun alasan "oportunis", perusahaan HTI di Provinsi Riau memilih mengeluarkan wilayah yang dipersengketakan dari perusahaan dan mengusulkannya menjadi daerah enclave. Namun demikian, tidak mudah mengubah kawasan HTI menjadi daerah enclave karena berkaitan dengan perubahan status kawasan hutan, meskipun fakta di lapangan sudah tidak sesuai lagi dengan fungsi hutan yang ditetapkan. Konflik juga dapat terjadi antara masyarakat yang dapat memanen hasil kebun dengan yang tidak dapat memanen hasil kebun karena tanamannya rusak akibat berbagai faktor (misalnya dilindas gajah).

Nurrohmat et al. (2014) menyatakan bahwa semakin banyak migrasi penduduk dari luar Riau untuk mengembangkan dan membuka lahan/perkebunan baru, maka semakin banyak konflik yang terjadi. Masyarakat pendatang ini dapat mengubah budaya masyarakat lokal dalam pembukaan lahan. Sebagian besar masyarakat membuka lahan bukan hanya untuk memenuhi kebutuhan ekonomi keluarga, tetapi sudah berpikir ekonomi secara luas dengan membuka lahan bahkan ribuan hektar.

Peningkatan skala usaha luas penguasaan lahan untuk budidaya komoditas komersial kelapa sawit, meruntuhkan bahkan melenyapkan budaya asli gotong royong atau tolong menolong dalam pembukaan lahan maupun persiapan lahan. Masuknya nilai uang dalam model pertukaran ekonomi, budidaya kelapa sawit dalam pemenuhan kebutuhan tenaga kerja, penggunaan alat dan mesin serta intensitas kapital yang tinggi, cenderung membentuk sistem nilai budaya yang eksklusif dan meninggalkan budaya yang ramah lingkungan.

Diperkirakan sekitar $90 \%$ masyarakat pembuka lahan adalah masyarakat perantauan yang sengaja datang, dengan membeli lahan kepada pihak yang (dianggap) berwenang, yaitu Kepala Desa. Adanya proses jual beli ditambah dengan risiko yang siap ditanggung para pendatang telah mengurangi ketelitian dan 
keingintahuan pembeli mengenai status lahan. Dorongan dan tarikan karena masalah ekonomi dan sumber nafkah menjadi faktor pemicu pembukaan lahan secara ilegal. Masyarakat pendatang yang mengalami kesulitan mengembangkan ekonomi di daerah asal, melakukan migrasi ke Provinsi Riau untuk membuka kebun.

Perambahan hutan dan lahan juga terkait dengan aspek mobilitas penduduk atau migrasi. Beberapa tahun terakhir, angka pertumbuhan penduduk di Provinsi Riau tergolong sangat tinggi. Angka pertumbuhan yang tinggi tidak hanya disebabkan oleh besarnya angka kelahiran, juga disebabkan oleh banyaknya warga pendatang yang masuk ke Provinsi Riau. Oleh karena itu, Pemerintah Provinsi Riau meminta kepada seluruh pemerintah kabupaten/kota untuk memantau dan menekan jumlah pendatang masuk ke Provinsi Riau, terutama pendatang yang tidak memiliki modal kerja dan keterampilan. Penduduk pendatang yang tidak memiliki keterampilan dan modal kerja yang cukup, berpotensi mendatangkan masalah sosial baru ditengah masyarakat yaitu pengangguran.

Perambahan hutan dan pembakaran yang tidak terkendali dalam penyiapan lahan untuk perkebunan memicu konflik sosial. Di sisi lain, semangat konservasi yang tidak terukur seperti perluasan kawasan lindung (taman nasional) ke dalam wilayah budidaya dan pemukiman penduduk di beberapa daerah telah memicu terjadinya konflik tenurial secara vertikal, yakni antara masyarakat dengan pemerintah. Perluasan kawasan konservasi tanpa dibarengi dengan peningkatan kuantitas dan kualitas aparat, justru mengakibatkan semakin meluasnya areal-areal terbuka karena kurangnya pengawasan tingkat tapak. Akibatnya, perambahan dan pembakaran hutan sering dijumpai di areal-areal eks pemekaran kawasan konservasi yang open acces karena kurangnya pengawasan

\section{Faktor Kebijakan dan Alokasi Ruang}

Gambar 11 menunjukkan bahwa semakin dekat jarak ke lokasi kawasan hutan baik hutan produksi (HP), hutan produksi terbatas (HPT), maupun hutan produksi konversi (HPK), maka semakin besar resiko terjadinya kebakaran. Tipe tutupan hutan senantiasa memiliki peluang terbakar yang relatif rendah bila berada dalam kondisi normal, namun perkembangan dewasa ini yang terjadi terhadap hutan alam yang terus menerus mengalami pembalakan baik legal maupun illegal, maka peluang terjadinya kebakaran sangat besar.

Berdasarkan hasil analisis sebaran titik panas, sebanyak 594 titik panas yang diduga titik kejadian kebakaran $(39,91 \%)$ berada tepat di hutan produksi, sebanyak 718 titik panas $(48,16 \%)$ berada pada jarak kurang dari $1000 \mathrm{~m}$ dari hutan produksi. Sedangkan di kawasan hutan produksi, ditemukan sebanyak 179 titik panas $(12,01 \%)$ berada tepat di kawasan hutan produksi konversi, sebanyak 316 titik panas $(21,19 \%)$ berada pada jarak kurang dari $1000 \mathrm{~m}$ dari hutan. Sekitar 20\% titik panas berada di kawasan hutan produksi terbatas, dan sebanyak 374 titik panas $(25,08 \%)$ berada pada jarak kurang dari $1000 \mathrm{~m}$ dari hutan produksi terbatas

Lokasi kawasan lindung seperti hutan lindung, kawasan suaka alam (KSA) atau kawasan pelestarian alam (KPA) jarang terjadi kebakaran hutan dan lahan. Hal ini dapat dilihat dari Gambar 12 yang menunjukkan bahwa hanya sekitar $1 \%$ titik panas berada di kawasan hutan lindung. Di kawasan konservasi, terdapat 93 yang diduga titik kejadian kebakaran (6.24\%) berada tepat di kawasan konservasi, 119 titik panas $(7,98 \%)$ berada pada jarak kurang dari $1000 \mathrm{~m}$ dari kawasan konservasi.

Gambar 12 menunjukkan bahwa semakin dekat jarak ke lokasi kawasan hutan lindung dan lokasi kawasan konservasi KSA/KPA, maka semakin kecil resiko terjadinya kebakaran atau semakin jauh jarak ke lokasi hutan lindung maka semakin besar resiko terjadinya kebakaran. Tipe tutupan lahan ini memiliki peluang terbakar relatif rendah dikarenakan pada kawasan hutan lindung telah dilakukan penataan batas yang jelas. Selain itu penegakan hukum terhadap kawasan lindung telah dilakukan secara tegas terhadap bagi siapa yang memasuki atau merambah kawasan lindung

Areal penggunaan lain (APL) merupakan areal yang dapat dimanfaatkan oleh masyarakat. Kawasan APL ini merupakan areal yang cukup rentan terhadap terjadinya kebakaran. Berdasarkan analisis sebaran titik panas, terdapat sebanyak $50 \%$ titik panas berada pada lokasi APL (Gambar 18) atau lokasi yang berjarak kurang dari $1 \mathrm{~km}$ dari APL ini. Gambar 
13 menunjukkan bahwa semakin dekat jarak ke lokasi kawasan APL maka semakin besar resiko terjadinya kebakaran, ini disebabkan sebagian besar masyarakat menggunakan api dalam kegiatan pembukaan lahan.

Kegagalan memahami akar masalah kebakaran hutan dan lahan sangat terkait dengan persoalan kebijakan. Walaupun kebakaran hutan dan lahan telah terjadi berulang, namun kebijakan penanganannya cenderung bersifat kuratif dibandingkan preventif. Pemerintah pusat maupun pemerintah daerah masih terkesan enggan mengalokasikan anggaran yang memadai untuk program-program pencegahan kebakaran hutan dan lahan. Secara umum besaran nilai anggaran untuk pencegahan kebakaran hutan dan lahan serta bencana asap masih dianggap kurang memadai dibandingkan dengan alokasi anggaran untuk pemadaman api.

Pendekatan kebijakan kebakaran hutan dan lahan selama ini terkesan masih sangat sektoral. Walaupun koordinasi telah diupayakan dilaksanakan tetapi dalam praktik di lapangan, kegiatan penanggulangan kebakaran hutan dan lahan cenderung tetap dilaksanakan oleh masing-masing sektor dengan koordinasi minimal. Hal ini disebabkan oleh kebijakan satuan anggaran yang sangat rigit sehingga kurang membuka ruang penggunaan dana untuk penanggulangan bencana di sektor lain. Sebagai contoh operasi manggala agni dibatasi pada kawasan hutan karena sulit untuk mempertanggungjawabkan penggunaan anggaran jika dipergunakan untuk pemadaman api di luar kawasan hutan.

Pendekatan kebijakan dalam menangani kebakaran hutan dan lahan seharusnya tidak hanya bersifat jangka pendek dan kasuistik, namun juga perlu memerhatikan berbagai potensi pemicu kebakaran secara komprehensif berbasis pengetahuan yang kuat. Sebagian orang beranggapan bahwa masalah kebakaran hutan dan lahan adalah persoalan yang mekanistis sehingga dapat diselesaikan dengan instrumen teknis. Sementara yang lainnya menganggap bahwa kebakaran hutan dan lahan hanyalah bagian dari rutinitas, sebagai konsekuensi dari budaya perladangan berpindah yang telah berlangsung lama walaupun realitasnya telah cukup lama terjadi pergeseran dalam budaya bercocok tanam.
Kebutuhan akan kebijakan yang operasional untuk mendeteksi modus dari beberapa jenis aktivitas di dalam kawasan hutan dan lahan gambut akan mampu secara efektif mencegah berbagai kegiatan masyarakat yang berpotensi menyebabkan kebakaran. Di sisi lain kebijakan yang buruk dapat menjadi faktor pendorong terjadinya kebakaran hutan dan lahan secara khusus kebijakan mengenai kebakaran hutan dan lahan yang sudah banyak diterbitkan, dari tingkat Undang-undang hingga tingkat eselon I lembaga terkait, bahkan sampai ke tingkat provinsi dan kabupaten/kota. Pada kebanyakan kasus, efektivitas kebijakan tersebut masih sangat rendah dan banyak celah. Selama ini kebijakan yang dilaksanakan masih bersifat sektoral dan terkesan kurang atau lemah dalam hal koordinasi, baik antar kementerian/lembaga pusat dan daerah. Pendekatan kebijakan yang digunakan tampaknya masih lebih banyak pada upaya pemadaman daripada pencegahan kebakaran hutan dan lahan.

Teknologi penginderaan jauh yang selama ini digunakan dalam pemantauan kebakaran hutan dan lahan (satelit NOAA atau sejenis) dapat digunakan sebagai salah satu informasi yang penting dalam sistem peringatan dini untuk mengetahui kondisi suatu lokasi dalam status peringatan atau telah terbakar. Pelibatan aparat pemerintahan di tingkat tapak, baik kecamatan maupun desa/kelurahan menjadi sangat penting dalam upaya pencegahan dan penanggulangan kebakaran hutan dan lahan. Selain itu, untuk membantu upaya pencegahan dan penanggulangan kebakaran hutan dan lahan, pemegang konsesi, baik perkebunan, kehutanan, maupun pertambangan diwajibkan untuk membentuk satuan patroli sekaligus satuan pemadam kebakaran hutan dan lahan.

Selain itu penegakan hukum terhadap masyarakat pembakar masih lemah. Pemerintah pada umumnya bersikap lunak kepada masyarakat perambah dan/atau pembakar lahan. Setiap terjadi kebakaran hutan dan lahan, pemerintah terkesan memilih bersikap populis dengan menetapkan tersangka "perusahaan". Pemerintah cenderung menghindari penetapan tersangka perorangan atau kelompok orang (masyarakat pembakar lahan). Padahal, orangorang yang membuka lahan dengan cara membakar tidak hanya masyarakat lokal, diduga lebih banyak dilakukan oleh sekelompok orang 
yang dikoordinir oleh cukong. Mereka disinyalir telah membuka lahan ratusan sampai ribuan hektar di berbagai tempat, termasuk pada kawasan konservasi (konsesi HTI), kawasan $\mathrm{HCV}$, maupun sempadan sungai.

Beberapa kebijakan pencegahan dan penanggulangan kebakaran hutan dan lahan yang diperlukan, antara lain :

a. Kebijakan pembukaan lahan tanpa bakar, yang didukung dengan adanya kebiajkan pemanfaatan limbah vegetasi/biomassa untuk keperluan bahan baku industri perkayuan yang terintegrasi dengan RPBI (Rencana Pemenuhan Bahan Baku Industri, Rencana Tata Ruang Wilayah (RTRW) kabupaten/kota maupun provinsi terkait kebijakan peremajaan kebun (replanting) secara serentak dalam suatu hamparan lahan tertentu. Hal ini penting agar limbah biomassa hasil peremajaan kebun dapat dimanfaatkan secara efektif, efisien dan memenuhi skala keekonomian

b. Penegakan hukum yang jelas dan tepat sasaran.

c. Kepastian pola penggunaan dan fungsi ruang.

Dalam perumusan kebijakan perlu ditekankan bahwa skema pencegahan dan penanganan kebakaran hutan dan lahan yang melibatkan peran aktif masyarakat akan jauh lebih efektif dibandingkan pemantauan yang hanya dilakukan oleh institusi tertentu. Oleh karena itu perlu dipertimbangkan untuk memberikan kewenangan pengelolaan lahanlahan konflik dan open access serta yang berpotensi sebagai sumber kebakaran untuk dikelola oleh desa, kelompok tani atau koperasi secara legal dan bertanggung jawab. Sistem pengelolaan lahan yang dilakukan harus disesuaikan dengan fungsi tata ruangwilayah tersebut. Pemerintah harus segera mengeluarkan kebijakan untuk meregistrasi dan mengatur pemanfaatan lahan-lahan hutan yang terdegradasi atau yang secara de facto telah beralih fungsi kepada lembaga di tingkat tapak (desa, koperasi, atau kelompok tani) yang bertanggung jawab terhadap keamanan dan pengelolaan lahan. Kebijakan tersebut sangat penting untuk mencegah terjadinya open acces lahan hutan yang sangat rawan terhadap perambahan dan berbagai kepentingan dari "penumpang gelap" yang memanfaatkan kawasan hutan secara ilegal dan tidak bertanggungjawab. Selama ini para pengambil keputusan terkesan enggan membuat terobosan dalam pengaturan pengelolaan kawasan hutan negara yang pada kenyataannya di lapangan telah dimanfaatkan oleh masyarakat, seperti lahan-lahan eks konsesi kehutanan (HPH) yang tidak aktif.

Berdasarkan analisis faktor biofisik lingkungan, sosial ekonomi dan kebijakan dan tata ruang terhadap sebaran titik panas, maka secara singkat dapat digambarkan bahwa jarak beberapa parameter atau input variabel memiliki keterkaitan yang cukup signifikan dengan terjadinya kebakaran lahan (titik panas), seperti lahan gambut, ijin usaha IUPHHKK dan HGU, kawasan hutan produksi, tutupan hutan dan kawasan areal penggunaan lain.

\section{SIMPULAN}

Hasil penelitian mengenai "Dampak Alih Kebakaran yang terjadi di Provinsi Riau sangat dipengaruhi oleh berbagai faktor seperti kondisi biofisik lingkungan, kondisi sosial ekonomi masyarakat dan penerapan hukum dan kebijakan terkait alokasi ruang.

Hasil analisis jarak lokasi titik panas menunjukkan kecenderungan bahwa jumlah titik panas semakin tinggi di areal lahan gambut (jarak $0 \mathrm{~m}$ ) hingga jarak 2.500 sampai $3.000 \mathrm{~m}$ dari lokasi gambut. Selain itu, ketersediaan akses jalan (aksesibilitas) yang dapat dipergunakan oleh masyarakat, meningkatkan peluang terjadinya kebakaran. Hal ini menunjukkan bahwa jarak yang semakin dekat dengan jaringan jalan akan meningkatkan peluang terjadinya kebakaran.

Aktivitas masyarakat dalam mengolah lahan pertanian/perkebunan dengan menggunakan metode tebas-bakar (slash and burn) merupakan salah satu faktor yang menyebabkan kebakaran hutan/lahan di Provinsi Riau. Berdasarkan analisis distribusi titik panas, sebaran titik panas yang cukup tinggi ditemukan hingga jarak $20 \mathrm{~km}$ dari pertanian lahan kering. Semakin dekat jarak dari pertanian lahan kering maka semakin besar resiko terjadinya kebakaran mengingat kegiatan pembukaan lahan seringkali menggunakan api.

Bahwa terdapat korelasi atau keterkaitan antara kebakaran hutan/lahan di Provinsi Riau dengan 15 variabel yang diamati, yaitu 
karakteristik lahan gambut, sungai, jalan, kondisi tutupan lahan (tutupan hutan, tutupan perkebunan, permukiman, pertanian lahan kering), perijinan (ijin usaha hutan tanaman industry, konsesi perkebunan), dan kawasan hutan (hutan produksi, hutan produksi terbatas, hutan lindung, dan areal penggunaan lain). Berdasarkan uji akurasi, model spasial regresi logistic yang dibangun dapat memprediksi probabilitias kejadian kebakaran hutan/lahan sebesar $90.96 \%$ di Provinsi Riau

\section{UCAPAN TERIMA KASIH}

Terimakasih saya ucapkan kepada Tuhan Yang Maha Esa atas berkat yang diberikan kepada saya. Terimakasih kepada semua pihak yang telah membantu baik material maupun non material demi mendukung saya dalam penelitian ini

\section{DAFTAR PUSTAKA}

Appanah, S. 1997. Peat swamp forest of Peninsular Malaysia: the endanger ecosystem. Pages in P. Havmoller, C. Tuek Yuan and Razani U. Eds. Proceedings of the Workshop on Sustainable Management of Peat Swamp Forest. Forstry Department Head-quarters and State Forestry Department Selangor. Kuala Selangor, 29 Sept-1 Oct. Malaysiaa-DANCED Project on Sustainable Management of Peat Swamp Forest. Malaysia. P.6-14.

Barber CV, Schweithhelm J. 2000. Trial by Fire: Forest Fire and Forestry Policy in Indonesia's Era of Crisis and Reform. World Resources Institute - Forest Frontier Initiative in Collaboration with WWF-Indonesia \& Telapak Indonesia Foundation.

Chowdhury, R.R., 2006. Driving forces of tropical deforestation: The role of remote sensing and spatial models. Department of Geography and Regional Studies, University of Miami, Florida, USA Singapore Journal of Tropical Geography, 27, pp. 82-101

Geist; H.J., Lambin E.F. 2002. Proximate causes and underlying driving forces of tropical deforestation. Bioscience, 52 (2), pp. 143

IBM Corp. Released 2013. IBM SPSS Statistics for Windows, Version 22.0. Armonk, NY: IBM Corp.

Jafarzadeh, A.A., Mahdavi, A., and Jafarzadeh, H. 2017. Evaluation of forest fire risk using the Apriori algorithm and fuzzy cmeans clustering. Journal of Forest Science, 63 (8), pp. 370-380

Jaya INS, Purnama ES, Arianti I, Jaruntorn B. 2007. Forest Fire Risk Assessment Model and Post-Fire Evaluation Using Remote Sensing and GIS: A Case Study in Riau, West Kalimantan And East Kalimantan Provinces, Indonesia. The Forest Restoration and Rehabilitation Training Course and Workshop, Viiki Tropical Resources Institute (VITRI), University of Helsinki, Finland, 13 19 May 2007

Miettinen, J. and Liew, S. C.(2005)'Connection between fire and land cover change in Southeast Asia: a remote sensing case study in Riau, Sumatra',International Journal of Remote Sensing,26:6,1109 — 1126

Nurrohmat, D.R., E, Sunarti, B.Barus, S.Ma'arif, Murdiyanto, A.D. Nurhayati, A.Yusuf, P. Irawansyah. 2014. Pembelajaran Penanggulangan Bencana Asap di Riau Tahun 2014. Pusat Studi Bencana LPPM IPB. Bogor.

Page S.E., Hooijer, A. 2016. In the line of fire: the peatlands of Southeast Asia. Philosophical Transaction Royal B. 371, p. 1-9.

Prasetyo,LB., Kartodihardjo, H., Adiwibowo, S., Okarda, B. and Setiawan, Y., 2009. Spatial model approach on deforestastion of Jawa Island, Indonesia. Journal of Integrated Field Science., 6, pp. 37-44.

Sahardjo BH. 1999. Study on Forest Fire Prevention for Fast Growing Tree Species Acacia mangium Plantation in South Sumatera, Indonesia. Kyoto University, Graduate School of Agriculture. p. 33-39.

Sahardjo BH. 1999. H. Watanabe, E.A. Husaeni and Kasno. 1998. The management of fuel and fire in land preparation for forest plantatiom and shifting cultivation. Wokshop on Fires and Sustainable Agricultural and Forestry 
Development in Easter Indonesia and Northen Australia. ACIAR Proc. No. 91, p.39-44.

Saito H, Sawada Y, Sawada H. 2002. The Development of the Forest Fire Risk Map. Indonesian Forest Fire and Its Environmental Impacts - The $15^{\text {th }}$ Global Environment Tsukuba - January 2002, CGER-1049-2002, CGER/NIES

Setiawan, Y. 2013. Study of Land Use Change in regional Scale of Java Island, Indonesia.

Setiawan, Y., Pawitan, H., Prasetyo, L.B, and Permatasari, P.A. 2017. Monitoring tropical peatland ecosystem in regional scale using multi-temporal MODIS data: Present possibilities and future challenges. IOP Conference Series: Earth and Environmental Science, 54, 012052

Syaufina, L. 2008. Kebakaran Hutan dan Lahan di Indonesia. Pola, penyebab dan dampak kebakaran. Bayumedia Publishing, Malang.
Singaravelu SS. 2002. El Nino, climate change and peat fires. Makalah disajikan pada Workshop on Prevention and Control of Fire in Peatlands, 19-21 March 2002, Kuala Lumpur, Malaysia, 9 h.

Verburg PH, Veldkamp TA, Willemen L, Overmars KO and Castella JC. 2004a. Landscape level analysis of the spatial and temporal complexity of land-use change. Geophycal Monograph-American Geophysical Union, 153, pp. 217-230.

Verburg PH, De Nijs, TCM, Van Eck JR., Visser H., and De Jong, K., 2004b. A method to analyze neighborhood characteristics of land use patterns. Computers, Environment and Urban System, 28, pp. 1327-1335.

Xie C, Huang B, Claramunth C, Chandramouli M, 2005. Spatial Logistics Regression and GIS to Model Rural-Urban Land Conversion. In Second International Colloqium on the Behavioral Foundations of Integrated Land-use and Transportation Model; Framework, Models and Applications. 2005 July, Toronto, Canada. 